\title{
BUILDING IDENTITY IN GLOBAL REALITY: A POSTCOLONIAL STUDY ON RAJAA ALSANEA'S NOVEL BANAAT AR-RIYADH
}

\author{
Hindun \\ Faculty of Cultural Sciences, Universitas Gadjah Mada \\ Email: hindun@ugm.ac.id
}

\begin{abstract}
This study aims to examine the novel Banaat ar-Riyadh (Girls of Riyadh) from the perspective of globalization using a postcolonial approach. This novel was written by Rajaa Alsanea, a Riyadhi girl who moved to the United States of America and then published her novel in Lebanon. The novel was written in the form of a series of electronic mails sent by four young Riyadhi girls who discuss the contestation between traditional Saudi Arabian norms and American norms. Fittingly, this study uses postcolonial theory, with the theoretical framework of globalization as a basis for investigating the aspects identified in the theory, such as mimicry, inferiority, and hybridity, and applies deductive qualitative method from a globalization perspective. The results of this study indicate the influence of American culture on the lives of Saudi Arabians. The influence of American culture is obtained through Saudi people, both men and women, who study and work in the United States. It is the relationship between Arab culture and American culture that influences the Arab way of thinking, which leads to certain behavioral changes. Some Arabs, previously compliant to their traditional values, display behavorial changes that are inspired by Americans, especially American women. Arab women who are supposed to constantly obey state rules, want changes which they adopt from American culture.
\end{abstract}

Keywords: globalization, postcolonial, postdiaspora, hybridity, Arab-American identity

\begin{abstract}
ABSTRAK
Penelitian ini bertujuan meneliti novel Banaat ar-Riyadh dari perspektif globalisasi dengan mengambil pendekatan poskolonial. Novel ini ditulis oleh Rajaa Alsanea, seorang gadis Riyadh yang pindah ke Amerika Serikat lalu menerbitkan novelnya di Lebanon. Novel ini berbentuk rangkaian surat elektronik yang dikirimkan oleh empat sekawan gadis-gadis Riyadh yang membicarakan kontestasi antara norma-norma tradisional Arab Saudi dengan norma-norma Amerika Serikat. Oleh karena itu, penelitian ini menggunakan teori poskolonial, serta globalisasi sebagai landasan untuk melihat aspek-aspek yang dikemukakan dalam teori tersebut, yaitu mimikri, inferioritas, dan hibriditas, dengan metode deduktif kualitatif yang ditempatkan dalam perspektif globalisasi. Hasil dari penelitian ini menunjukkan adanya pengaruh budaya Amerika pada tata kehidupan sebagian orang Arab Saudi. Pengaruh budaya Amerika itu diperoleh melalui orang-orang Arab Saudi, baik laki-laki maupun perempuan, yang menempuh studi dan bekerja di Amerika. Keterhubungan antara budaya Arab dengan budaya Amerika inilah yang memengaruhi pemikiran orang Arab, yang kemudian berdampak pada perubahan perilaku. Orang Arab yang semula berpegang teguh pada aturan-aturan tradisi kemudian menginginkan perubahan-perubahan yang mengarah pada pada perilaku orang Amerika yang mereka lihat, terutama pada perempuan. Perempuan Arab, yang diharuskan patuh pada aturan-aturan yang dibuat oleh negara, menginginkan perubahan-perubahan dengan mengadopsi budaya Amerika.
\end{abstract}

Keywords: globalisasi, poskolonial, posdiaspora, hibriditas, identitas Arab-Amerika 


\section{INTRODUCTION}

Globalization is an inevitability that arises from the fusion of regional and social boundaries between countries of the world. Set off from various regions of the globe, both directly and indirectly, the flow of information connects humans to one another. Moreover, experts argue that globalization is an intensification of social relations between various regions of the world, which certainly has impacts on the conditions of different societies. The interactions of individuals, groups, and nations across borders of nationalities generate situations that mutually affect one another, and the Arab world is no exception.

The most prominent thing in the connection between the Arab world and other regions is human movement in various fields, one of which is culture. Such connection has resulted from cultural globalization, marked by technological advancements at the beginning of the $21^{\text {st }}$ century. Occurring through media such as the internet and television, this connection has replaced physical contacts as the primary means of international communication. These changes make international communication easier to do, which in turn accelerate mutual influencing that bring about, among others, changes in identity. For example, some Saudi Arabians view the independence of American women as an ideal that they wish to realize because it is the complete opposite to of the situation in Saudi Arabia with its many constricting rules regarding women.

Women make up the group most disadvantaged by the country's prevailing rules, such as the prohibition on having a bank account, driving, working in public domains, and leaving the house without a male guardian or mahram, alongside the more common obligation such as wearing the abaya and the veil when leaving the house. On the other hand, Arab people, especially Saudi Arabians, are exposed to a global influence through social interactions with other nations, such as when studying or vacationing abroad, as well as through digital interactions through social media which introduce them to nations with cultures that are different from theirs.

The representation of the effects of globalization on Saudi Arabia can be seen in Rajaa Alsanea's novel Banaat ar-Riyadh (Girls of Riyadh). This novel tells the problems of four Arabian girls found through their conversations via series of emails on a online subscription list. The publication of this novel first in Arabic in 2005, and then in English in 2008 - became significant after the author, Rajaa Alsanea, left Saudi Arabia to live in the United States. The novel was published in Lebanon because it was impossible to publish it in Saudi Arabia due to the prevailing rules. The novel Banaat ar-Riyadh represents globalization issue as new identity of Arabian through some perspective of Saudi Arabian. The emergence of a new identity in the globalization paradigm requires further investigation, giving raise to questions as to how the construction of identity in a global reality is found in the novel, and how the relationships between its characters represent the meeting of two different cultures (hybridization).

The emergence of Rajaa Alsanea's Banaat arRiyadh attracted reporters/researchers to analyze her work from various viewpoints. Raid Qusti, for example, discussed in 2006 about the circulation of the novel Girls of Riyadh in bookstores in Saudi Arabia. In 2010, both Ware and Booth delved into the book's translation, with Vron Ware exploring a wider range of questions posed by the subject matter, style, translation, and marketing of this book, and Booth taking the translation of the novel into English as a case study for the politics of translating Arabic.

Using a feminist approach, in 2013, Amirah Anis Thalib wrote in her thesis how Saudi women are described in the novel to be living under male domination. Similarly, Arika and Ramadhani (2018) explain in their article that their study found images of feminism in the novel. Moreover, Sumayyah (2019) in her doctoral thesis titled "Identity Crises in Contemporary Saudi Arabian Women's Writing” explores a range of works by contemporary Saudi women writers.

Using a sociological approach, Syahril (2014) explains in his article that the novel shows symbolic violence in several forms, namely symbolic state violence against society, men against women, and parents against children. Similarly, Ahgahtani (2016) examines how the socio-cultural contexts have affected readers' responses to particular Saudi novels. Some responses to Saudi authors are based on the ideological belief that their novels consist of acts of rebellion against a conservative culture.

Based on existing research maps, this research analyzes the construction of identity in the era of globalization as portrayed in the novel 
Banaat ar-Riyadh within the theoretical framework of globalization. Furthermore, in order to map the relations between the characters in the novel, the concept of hybridization was adopted to reveal the construction of hybridity in the novel.

Globalization refers to connections between many countries and nations, and such connections are believed to have impacts on the way that people think and behave, as argued by Held and McGrew (2002: 2) that globalization is "the widening, deepening and seeping up of world-wide interconnectedness in all aspects of contemporary social life, from the cultural to the criminal, the financial to the spiritual." Moreover, Waters (1995) defines globalization from quite a different point of view. According to him, globalization is a social process in which geographical boundaries are no longer important for socio-cultural conditions, and that it eventually manifests within individuals' consciousness.

Both definitions, however, can be traced in Giddens's (2013) view that globalization is dependency between one country and the others, between one man and the others, through trades, travels, tourisms, information, and other intensified interactions, so that national boundaries gradually no longer exist. On the other hand, Tomlinson (1999) defines globalization as a shrinking of distance taken and a reduction of time needed to carry out various daily activities, either physically (such as traveling by air) or representatively (such as the distribution of information and images using electronic media). Globalization can also be seen as something that affects aspects of people's lives, including cultural aspects. In order to see changes in values and identity in society, which is an effect of imperialism, it is necessary to employ a postcolonial approach.

Homi Bhabha (1994) proposes a concept of cultural hybridity. He developed ideas about postcolonial studies by focusing on culture, emphasizing that what is presented in the world today is a manifestation of a representation of cultural hybridity. Hybridity, then, is a product of cultural assimilation. According to Bhabha, the identities of the colonized and the colonizer constantly change and continuously support each other. Through the concept of hybridity, the culture of globalization later gives birth to the so-called cultural homogeneity, which is cultural uniformity due to the mixing of cultures, in which eastern countries absorb western culture.
The concept of hybridity has been widely used to solve problems in the relations between the colonizers and the colonized, which tend to be unbalanced. In practice, hybridity tends to emphasize the meeting of two different cultures. According to Foulcher \& Day (2008: 12), the term hybridity is used to refer to interactions between different cultural forms that can generate the formation of new cultures and identities with their own history and textual manifestations.

In Limits, Transformations, and Prospects, Prabhu (2012) defines hybridity in general as a cross-cultural exchange. She takes two terms to refer to the process of hybridity or hybridization, namely diaspora and postdiaspora. As concepts, diaspora and postdiaspora are conflicting terms. Both are strategies used for analyzing and understanding the discourse of hybridity. Basically, diaspora is hybridity based on a single identity in which the presence of others is not desired, and therefore the movement leads to an original identity. On the other hand, postdiaspora is hybridity based on an open identity which tends to embrace assimilations.

Theoretically, the postdiaspora discourse is related to the elimination of past trauma, directing a particular energy towards new interactions and connections in the present. The postdiaspora discourse works to combat one domination, one canon, one mode of thought, single identity, linear history, and so forth (Prabhu, 2012 : 5). The postdiaspora discourse will hinder the power of cultural hegemony, thus restructuring what supports and allows cultural hegemony.

Prabhu took several ideas from other theorists for his use of the term postdiaspora. Stuart Hall, for example, uses 'diasporization,' which Prabhu considers to encompass postdiaspora. Hall (1997) provides an example of the process of hybridity (hybridization) in the improvisations made by Black jazz musicians, rappers, etc. in their works as "unsettlement, recombination, hybridization and 'cut-and-mix' arising from 'diaspora experiences'. Therefore, art is something that is able to shape society as a 'new kind of subject"' (Prabhu, 2012 : 9). This is what Prabhu refers to as postdiaspora.

Based on the explanation above, hybridity is regarded as a critical strategy towards the impact of colonialism, which can be used as a basis to see the discourse of globalization that appears in the novel Banaat ar-Riyadh, especially in identifying the new 
identity implied in the novel.

\section{FINDING AND DISCUSSION}

\section{Social Condition of Saudi Women}

Saudi Arabian women make up a group that can be deemed marginalized - aggrieved in one way or another by the larger community. The Saudi government enforces special rules for women. The rules concern 14 aspects, namely: marriage (a woman cannot get married without her guardian's consent); divorce (a married woman cannot get a divorce without her husband's consent); custody (if a woman is divorced, she is granted the custody of her son until the age of seven, and of her daughter until the age of nine); passport (a woman is unable to register for a passport without her guardian's consent); travel (a woman is not allowed to go too far away from home without her guardian's permission, and she is not allowed to go only by herself); upon release from prison (a woman who has served prison time is not allowed to be free without her guardian's consent, even though her sentence is over); bank account (women and underage children are not allowed to register for a new bank account without their guardians' consent); employment (there are jobs available for women to pursue without the requirement of consent, but many Saudi companies refuse to hire women); garments (women are required to always wear a long, black robe called the abaya); interaction with men (women are prohibited to talk with men who are not their mahram in public places); testimony (the value of a woman's testimony is half that of a man); inheritance (a woman's inheritance right is half that of a man); medical services (a woman who is in need of medical services should be granted the permission of her guardian first, even in an emergency); and driving (women are not allowed to drive cars). To date, only the rule regarding driving has been revoked, namely since June 2018 (KumparanNEWS, 2017).

Upon careful observation, some of the the aforementioned rules are based more on local culture than on principles of Islamic jurisprudence. Therefore, it can be said that:

Saudi society is a unique mix between religion and culture, which poses difficulties for the government over education for women. The position of women in this society is complicated and they have to face a lot of barriers to get an education as they live under male authority all the time (Al Alhareth et al., 2015: 124).

To enforce these rules, the government has established a religious police team called muttawa or mutaween. They patrol parks, malls, restaurants, and other public places to seek, for instance, women and men who are mingling and make sure that they are married couples or have mahram relations. The mutaween is also in charge of eradicating drug abuse and monitoring the cyber activities of Saudi citizens (Graham-Harrison, 2016).

\section{Hybridity in Globalization}

This novel conveys the dream of women in Saudi Women to live their lives like women in a more liberal country like the United States of America. When they lived in the States, be it to pursue higher education or to make a temporary visit, they felt freedom, even in doing simple day-to-day activities. However, when they returned to Saudi Arabia, they went back to being trapped by strict rules. They then channel their thoughts and frustrations into emails on the online subscription list. They hope that their emails can encourage women like "matches" that "set thoughts on fire, the lighter that fuels a blaze of change" (Alsanea, 2004: 2). The characters in this novel have all come into contact with life in the United States. The first is a family of four: a Saudi man, his American wife, and their two children, Mashael and Mesh'aal. The man went to college at Stanford University and met his wife there. The couple then stayed in the United States after the husband had finished college and found work. Years later, they moved to Saudi Arabia. The following lines describe their relocation:

$$
\begin{aligned}
& \text { بينما لم تنضم إليهما مشاعل عبد الرمن أو ميشيل كما يناديها الجميع إلا } \\
& \text { في السنة الثانية من المرحلة المتوسطة، بعد أن عادت مع أبويها و مشعل } \\
& \text { الصغير - ميشو - من أمريكا. انتقلت بعدها بسنة إلى مدرسة تعتمد على } \\
& \text { اللغة الإنجليزية في مناهجها كلغة أولى }
\end{aligned}
$$

Mashael Abdurrahman - or Michelle, as we knew her - didn't join them until the second year at middle school, after she returned with her parents and little Meshaal - or Misho - from America. Only a year after Michelle came back to her home country to live, she transferred to a school where all the classes 
were taught in English. (p. 6)

Their American encounter began when Mashael's father, a Saudi man, studied in the United States. After graduating, he continued to live and work there. He later married an American woman, had two children, and raised them the American way. The children had grown into their teen years when they moved to Saudi Arabia and had to adapt to the Saudi way of life. The impact of Western/American culture on the family can be seen in the hybridity of the children's double names - Mashael/Michelle and Mesh'aal/Misho. The hybridity is inevitable for the Abdurrahman family, and its symptoms become palpable when the family move to Riyadh. Abdurrahman, who has been Americanized formally through education and culturally through his friends and family in the States, gives his daughters more freedom in his home country. Abdurrahman transfers Michelle to a school where all the classes are taught in English and the students come from various cultural backgrounds.

Next we have Rashid at-Tanbal, a student who pursues higher educations in the United States. He earns his bachelor's degree in Los Angeles, his master's degree in Indianapolis, and his doctoral degree in Chicago.

$$
\begin{aligned}
& \text { توجهت قرة مع عريسها إلى شيكاجو، التي اختارها ليبدأ فيها تحضيره } \\
& \text { للدكتورة في التجارة الإلكترونية، بعد أن حصل على درجة البكالوريوس } \\
& \text { في لوس أنجلس، و الماجستير في إنديانابوليس }
\end{aligned}
$$

Gamrah and her husband went to Chicago where he was working for his $\mathrm{PhD}$ in electrical engineering, after getting his BA in Los Angeles, and his master's in Indianapolis. (p. 14)

It can be seen from the three educational degrees that Rashid has been in the United States long enough for hybridity to take place either slowly or quickly.

Hybridity also occurs in Sadeem's family. This can be seen in the following quote.

$$
\text { بعد رسوب سديم المفابئ للمميع و هي المعرفة بتفوقها، اقترح والدها }
$$

$$
\text { من الوقت نفسها }
$$

After Sadeem flunked out of school, which came as a huge surprise to everyone since she was known for her academic excellence, her father proposed that the two of them travel to London for some fun. Sadeem asked him, though, to let her go alone and stay in their flat in South Kensington because she wanted to spend more time with herself. (p. 35)

Sadeem's father is a successful businessman not only in Saudi Arabia, but also in the United Kingdom, specifically London. The father has an apartment in London, which he would occupy whenever he is there on a business trip or on a vacation with Sadeem. This information gives us a glimpse of how hybridity also takes place in Sadeem's life. Out of free will, a privilege rarely given Saudi women, Sadeem goes to London on her own and stays in the apartment all by herself. Although far from the United States, London can be said to be more similar in culture to some cities in the United States than anywhere in Saudi Arabia.

With globalization, hybridity can also take place through technology. This novel is set at the beginning of the social media era, with a Yahoo subscription list being the characters' communication platform of choice, which also happened to be an American product. On the other hand, hybridity can be seen in the behavioral and perspective change of young Saudi women (and men) in general, as can be seen in this quote:

$$
\begin{aligned}
& \text { إلى من أزيجوني بحكاية أنين لا أمثل فتيات السعودية: كم مرة ينبغي لي }
\end{aligned}
$$

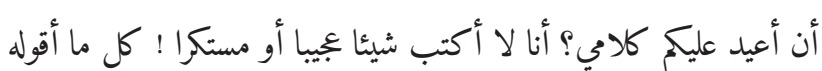

$$
\begin{aligned}
& \text { تعرفه البنات جيدا في مجتمعي أو محيطي... فأرجو من لا ناقة لهم و لا } \\
& \text { جمل عدم حشر أنوفهم لا يعنيه، و أن يتفضلوهم بالكخابة عن البنات إن } \\
& \text { إرادوا من أي زارية أخرى غير التي أراهن منها }
\end{aligned}
$$

To those who have totally annoyed me by declaring that I do not represent the girls of Saudi Arabia, I say: How many times do I have to repeat myself? I am not writing anything incredible or bizarre or so weird. Everything I say, the girls in my society know very well. I ask those who have nothing to do with what I say 
and they are welcome to write their different point of view to mine. (p. 104)

Through these words, the author informs us about the changes that are underway in Saudi Arabia. Its youth prefer to speak in English than in Arabic. They use Western names. They tend to eschew rules regarding mahram. They would rather study abroad, particularly in the United States, than in their own country. The stories published weekly on the Yahoo platform receive many positive comments from readers of various backgrounds from all over the world, both male and female, but they also inflame negative reactions from the Saudi society itself. Moreover, there are those who can certainly relate to what the author is describing in the novel, identifying themselves with the characters and feel that they are part of the stories being told. These situations indicate hybridity in a globalized world.

\section{Establishing the Idealism of Postdiaspora Equality}

In the novel, the author pens down these words: "They were energetic, independent, and strong" (Alsanea, 2004: 25) as an idealism. Those are the traits Saudi women wish to possess to be equal to men in society. Culturally, energetic, independent, and strong are not traits of Saudi Arabian women. The way the novel puts it: "woman is butter and man is sun" (p. 7), which means that women must be obedient and submissive to the rules enforced by the government and the patriarchal society. Moreover, the government's policy directs the education of women to prepare them for domestic roles. As Rajkhan puts it, "The Kingdom`s policy on education stresses that a girl's education targets to give her the appropriate Islamic education that will equip her with the necessary set of skills to become a good wife and an excellent mother" (2014: 3).

The idealism of postdiaspora equality in this novel is depicted through education. Saudi Arabian women fight for equality in education so that they can play an active role in both domestic and public domains. Alsaleh notes that "[w]omen in Saudi Arabia, like women in any country, have their perception of equality. They play an important role not only within the family but also outside their families" (2012: 123).

The female characters in the novel are described as educated people, as shown by the following passage:

$$
\begin{aligned}
& \text { استمرت حتى بعد انتقالهن للجامعة. درست سديم إدارة الأعمال، و اتجهت } \\
& \text { لميس نحو دراسة الطب، بينما اختارت ميشيل علوم الحاسب. أما قرة } \\
& \text { التي كانت الوحيدة المتخرجة من القسم الأدبي بينهن. فقد احتاجت }
\end{aligned}
$$

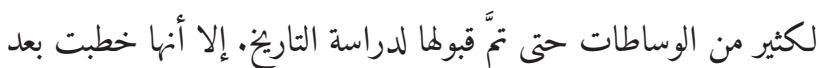

$$
\begin{aligned}
& \text { بداية الدراسة بأسابيع قليلة }
\end{aligned}
$$

'The friendship continued until they were in college, Sadeem studied business management, while Lamees went to medical school. Michelle decided on computer science. Gamrah, the only one among them who wasn't so keen on her studies in high school, needed to use pull from several family friends to get accepted to college as a history major, one of the easy fields to get into in college' (Alsanea, 2004: 6)

These are a group of young women. Sadeem is a student of Economics and majors in business management. She comes from a wealthy family as her father has businesses in Saudi and England. Lamees Jaddawi is a medical student who was born and raised in Riyadh. Her parents hail from Jeddah, a famous port city with a culture so mixed that it is known as the most liberal city in Saudi Arabia. Mashael or Michelle Abdurrahman is a student of computer science. She was born in the United States to a Saudi father and an American mother, spent her childhood in the United States, and moved to Riyadh in her adolescence with her parents. Gamrah al-Qusmanji's family is from Qasim, an ultraconservative city. She entered college only to drop out to get married shortly afterward.

These characters want to shape themselves and women in their society so that they can be independent and strong. With their degrees, they hope that they can work in the same institutions as men, and have the self-confidence that they need so as not to permanently live under the dominance of men. They gain this ideal from family members who were accustomed to western culture, especially American culture, as well as from their intensity in connecting with the world outside of Saudi Arabia, either physically or through technology.

Pursuing a higher education is important for Saudi Arabian women to manifest their hope for equality. The idealism of postdiaspora promotes that higher education for women justify equality between 
men and women. Characters in the novel that complete higher education get partners of equal standing, and they can also play an equal role in their domestic lives. In the novel, we meet Lamees and Michelle. Lamees has completed her study and is now training at a hospital in Jeddah. She gets assigned to the same room as another doctor, a man named Nizar. Since they are equally educated, they have no boundaries in getting along with each other.

لم تحتج لميس لفترة طويلة حتى تعتاد على عفوية نزار و تعجب بشخصيته

المهذبة. بدأ الحوار ما بينهما يتجاوز خطوط الطب و طرق العلاج و

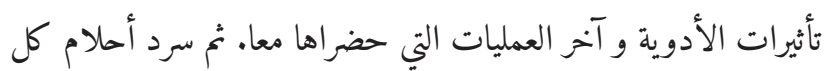

منهما لنفسه و تصوراته لحياته بعد التخرج ليصل إلى حياتهما الشخصية و

جذور عائلتهما و عدد الأخوة و الأخوات و المشاكل اليومية الصغيرة

و غيرها من الأحاديث التي تشير إلى أن ثمة ثلجا قد تكسر

Lamees didn't need very long to get used to Nizar's impulsive ways and appreciate his wellmannered personality. Their conversations began to go beyond the confines of medicine and various treatments and the latest drugs and surgical techniques. They told each other their dreams and what they imagined life would be like after graduating. Eventually, they talked about their personal lives and families, how many brothers and sisters each had, their daily problems and others that showed that the ice was now completely broken. (p. 114)

As for Michellle, after graduating from the Department of Media at the American University in Dubai (AUD), she gets a job with Arab Satellite Television Channels, where she gains a new horizons. She feels truly liberated from all the restriction that used to be imposed on her.

$$
\begin{aligned}
& \text { تعرفت على أنواع مختلفة من البشر و شعرت بأنها أكثر ثقة بنفسها و بأنها } \\
& \text { تستطيع تحقيق كل ما تريد بصداقتها الواسعة و علاقتها الكثيرة. كان } \\
& \text { •الجميع يحبونها و كانت تقابل محبتهم بالمزيد من التميز و النجاح }
\end{aligned}
$$

As she came to know different sorts of people, she began to feel increasingly confident and ambitious at work. She made networks and contacts. Everyone there adored her, which motivated her to produce even better work. (p. 117)

Higher education is key to women's transformation into more energetic, more independent, stronger human beings. The idealism of postdiaspora should be realized so that women can achieve equality in every field of job, to become confident and be able to expand their abilities, and to become independent and strong enough to define their own lives. This principle should encourages women to create their own identity and not merely wait for some changes in their social communities to take effect.

\section{Postdiaspora Hybridity Symbols}

Postdiaspora hybridity symbols are manifested through physical symbols. In this novel, the symbols take the forms of fashion style that hybridizes Western taste, celebrating Valentine's Day, throwing a bachelorette party and drinking alcohol, women working in public domain, and giving oneself a Western-sounding nickname.

The symbol of fashion style that hybridizes Western taste can be seen when Rashid marries Gamrah. Rashid wants her to dress like an American and asks her to open her veil in public. In his words, "Why don't you wear ordinary clothes like the other women here? It's as if you are trying to embarrass me in front of my friends with the things you wear! And then you wonder why I don't take you out with me!" (Alsanea, 2004:28-29). In his attempt to change his wife's appearance to be more American, it is clear that Rashid has no intention of preserving his original Saudi culture.

Not only does Rashid want Gamrah to change her outward appearance, but he may also want her to change her attitude. Later in the novel, an Asian girl named Kari who claims to be Rashid's ex-girlfriend before he married Gamrah, tells her:

$$
\begin{aligned}
& \text { يسعدني طبعا أن تريني حتى تكوني فكرة عما يحبه زوجك. لقد عاني راشد } \\
& \text { الكثير و لا بد أن تعلمي على تحسين نفسك من الداخل و الخارج حتى } \\
& \text { ترتي للمستوى الذي يهتويه حتى ترتقي لمستواي }
\end{aligned}
$$

It pleases me, naturally, for you to see me, so 
that you can form an idea of what your husband loves. Rashid has suffered a lot, and you must work to improve yourself, from the inside and out, so that you can move up to the standard he wants and needs. So that you can come up to my level. (p. 49)

The previous two passages show the irony of how, in his wish for her wife to change, Rashid actually becomes an extension of the Saudi culture that demands women to submit to their husbands' wishes.

Fashion-related hybridity is also presented through the character Sadeem. Before her plane lands at Heathrow Airport, Sadeem goes to the lavatory where "she took off her abaya and head covering to reveal a well-proportioned body encased in tight jeans and T-shirt" (p. 35). Abaya - a black Saudi dress for women that covers the entire body - and veil are part of Saudi women's clothing code and wearing them is in line with the government's regulation. This is believed to be no longer suitable for young women nowadays.

Another postdiaspora symbol is the celebration of Valentine's Day on February 14 as the day of love. Although prohibited in Saudi Arabia, some of its citizens have been celebrating it since the late 1990s after finding out about it through satellite TV from Lebanon and Egypt. A form of celebration of the day is described in the novel as below:

$$
\begin{aligned}
& \text { في الفالنتين أو عيد الحب، ارتدت ميشيل قيصا أحمرا و حلت حقيبة } \\
& \text { من نفس اللون، و كذلك بالنسبة إلى شريحة كبيرة من الطالبات فاصطبغ } \\
& \text { الحرم الجامعي باللون الأمر، ثيابا و زهورا و دمى. كان العيد أياهما تقليعة } \\
& \text { جديدة استلطفها الشبان الذين صاروا يبجولون في سيارتهم في الشوارع } \\
& \text { مستوقفين كل فتاة جميلة ليقدموا لها وردة حمراء ملفوفا على ساقها الرقم. } \\
& \text { و استلطفها الشابات اللواتي وجدن أخيرا من يهديهن ورودا حمراء كما }
\end{aligned}
$$

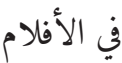

On Valentine's Day, Michelle put on a red shirt and carried a matching handbag. A large number of the other female students did the same, enough of them so that the whole campus looked bright red, by means of clothes and flowers and stuffed animals. In those days, the holiday was still a really new fad and the guys liked it; they cruised the streets stopping every girl they saw to give her a red rose with their phone numbers wrapped around the stem. The girls liked it, too, since now they had finally found someone to give them red roses the way they always saw it done in films. (Alsanea, 2004: 33)

Instead of throwing parties, the students celebrate the day in between their campus activities. The girls wear red dresses and purses, while the boys carry red roses that they hand out to the girls as they pass by, with their telephone number written on a piece of note attached to the flower. In their own way of celebrating Valentine's Day, they have successfully hybridized Western culture into their lives as a symbol of postdiaspora hybridity.

The third postdiaspora symbol can be seen in one bachelorette party. A bachelor/bachelorette party, common in the United States and Europe, is a party where a man or a woman and his/her friends celebrate his/her last day(s) as a single person before getting married. The four characters in this novel throw a bachelorette party before Gamrah's wedding.

$$
\begin{aligned}
& \text { أعدت الشلة ترتيبتها الخاصة قبل حفلة العرس لعمل ما يشبه الباتشلوريت } \\
& \text { بارتي التي يقمنها للعرس في الغرب قبل زفافها }
\end{aligned}
$$

Before the wedding, their little clique - the syillah - had made special preparations for its own intimate precelebration like the bachelorette party that, in the West, friends of the bride throw for her before her wedding. ( $p$. 8)

In a bachelorette party, the future bride and her friends usually dance to the accompaniment of a professional singer and a band. However, this small clique wants to hold a bachelorette party their own way. Gamrah and Sadeem wear abaya, while Lamees and Michelle wear men attires. This is done because Michelle will drive the car (driving car for women was not allowed at the time of the novel's setting). Their plan is to go to a restaurant until late at night to enjoy food and drink alcoholic beverages together. The presence of women disguised as men as their mahram - family members with whom marriage would be illegal - enables them to go out until late at night.

Before June 2018, as a religious prohibition, 
women in Saudi Arabia were not allowed to drive cars for moral reasons. Meanwhile, other Arab countries as well as non-Arab countries with high Muslim populations do not implement such prohibition, making it a highly contested regulation. Shekh Abdullah Mutlaq, a professor in comparative law and a former judge in the court of Hail City, Saudi Arabia, said in June 2009 that "there is no legitimate justification that prevents women from driving," and he also pointed out "the need to launch an awareness campaign for young people to respect women who drive and as such to acclimatize everyone until it becomes a normal sight" (Rajkhan, 2014: 25). The prohibition against driving for women was finally lifted ten years after petitions were raised.

The fourth diaspora symbol lies within Sadeem, one of the four girls, who gets accepted to work at the HSBC Bank in London as an intern. She feels comfortable working there, especially since there is not a single Saudi other than her working at the bank. As the novel describes it, "even better if there wasn't a single other Arab among them, so she felt free to act as if she were one of them, joking with this one and laughing with that one" (Alsanea, 2004: 61). Sadeem feels that she can have a normal life when she does not have to live in accordance with the Saudi culture. She does not have to wear the abaya and the veil, and can freely talk with her colleagues in the office. She can even accompany her coworkers to the bar, play the piano in public places, and go to the cinema. All of these things are impossible for Sadeem in Saudi Arabia. This can be inferred from the part where after she meets Firas, a Saudi man, she constantly thinks about encountering other Saudi people and worries about their views on her.

$$
\begin{aligned}
& \text { اقترح عليهم إدوارد بعد انتهاء الدوام في أحد الأيام أن يذهبوا جميعا } \\
& \text { إلى البيانو بار على هاي ستريت كنزنجتون. وقفت سديم على المجيء مع } \\
& \text { جمجوعة من الموظفين لوجود طاهر من ضنهم، و لأن البار الذي يريدون } \\
& \text { الذهاب إليه لا يبعد كثيرا عن شقتها لكنها أعلنت أنها ستنصرف عندما } \\
& \text { يأتي صديق طاهر لاصطحابه لمشاهدة فيلم في السينما. فطاهر صار مثل } \\
& \text { الأخ الأمبر الذي تشعر في وجوده بالراحة و الاطمئنان }
\end{aligned}
$$

One day after the bank closing, Edward suggested that they all go to the Piano Bar on Kensington High Street. Sadeem agreed to come, since a whole group of people including Tahir because the bar they were heading for was not far from her apartment. She announced that she would leave whenever Tahir did. Tahir become like a brother in whose presence she felt relaxed and secure. (p. 61)

Sadeem manages to complete her internship in London comfortably, but when she later graduates from college, she might not easily get a job. In her country, very few women get the opportunity to work, as in reality "Saudi Arabia is considered to have one of the lowest female employment rates in the whole region of the Middle East" (Rajkhan, 2014: 3).

The fifth symbol comes in the form of giving oneself Western nicknames. One of the novel's characters is Michelle, but that is not her real name. Her birth name is Mashael, a common first name among Arab societies. However, Mashael's family used to live in the United States, and the family actually feel more comfortable calling her by a Western name. Hence Michelle, and her brother, Meshaal, becomes Misho.

The discussion above shows how the four characters in this novel do not simply copy American culture, but they also dismantle it using their own understanding and their power as women to define what they believe in.

\section{CONCLUSION}

Several acts of hybridity performed by the female characters in the novel Girls of Riyadh are a struggle against male domination in Saudi Arabia. Moreover, they are forms of rebellion to the rules imposed by the Saudi Arabian government in ways that suppress women. Hybridity is not about changing oneself to become someone else, it is about being oneself but with better conditions.

The impacts of globalization, particularly the influence of American culture on Saudi culture discussed in the novel Girls of Riyadh, has given rise to a new identity, namely a postdiaspora community. This new identity has surpassed previous constructions, namely a diaspora that brought trauma and memories of the past over the country. On the other hand, the postdiaspora presented in this novel shows the construction of a new identity that is not related 
to trauma and memory in the past, but against the dominance of uniformed thought and identity. This new identity does not change the Saudi society into an American one, but instead hybridizes the values that are considered good and suitable with the original culture.

\section{REFERENCES}

Al Alhareth, Y., Al Alhareth, Y., \& Al Dighrir, I. (2015). Review of Women and Society in Saudi Arabia. American Journal of Educational Research, 3(2), 121-125.

Algahtani, Noura. (2016). "The Impact of Socio-Cultural Contexts on the Reception of Contemporary Saudi Novels" in Sociology Study Vol. 16 No 2, 104-110 February 2016. David Publishing.

Alsaleh, S. A. (2012). Gender inequality in Saudi Arabia: Myth and reality. International Proceedings of Economics Development \& Research, 39(1), 123-130.

Alsanea, Rajaa. (2004). Banāt ar-Riyadh. Beirut: Join Aafaq Group.

Arika, Merdu dan Novi Ramadhani. (2018). “AnNiswiyah fi Riwayah Banaat ar-Riyadh li Rajaa Abdullah Alsanea" in Bulletin al-Turas Vol 24, No 1. Jakarta: Faculty of Adab and Humanities, UIN Syarif Hidayatullah.

Bhabha, H.K. (1994). The Location of Culture. London dan New York: Routledge.

Booth, Marilyn. (2010). "The Muslim Woman" as Celebrity Author and the Politics of Translating Arabic: Girls of Riyadh Go on the Road" in Journal of Middle East Women's Studies Vol.6, Number 3, Fall 2010. Indiana University Press. p 149-182

Foulcher, K., \& Day, T. (2008). Sastra Indonesia modern: Kritik postkolonial. Jakarta: Yayasan Obor Indonesia.

Giddens, A. (2013). The Consequences Of Modernity. New Jersey: John Wiley \& Sons.

Graham-Harrison, Emma. (2018). Saudi Arabia Issues First Driving Licences to Women. Dari laman http://theguardian.com.world/2018/jun/05/. Accessed on July 18, 2018.

Hall, S. (1997). The work of representation. Representation: Cultural Representations and Signifying Practices, 2, 13-74.

KumparanNEWS. (2017). 5 Kebijakan Baru Arab Saudi yang "Membebaskan" Perempuan. Rabu, 27 September 2017. Accessed on July 18, 2018.

McGrew, A., \& Held, D. (2002). Governing Globalization: Power, Authority And Global Governance. Cambridge: Polity Press.
Prabhu, A. (2012). Hybridity: Limits, Transformations, Prospects. New York: SUNY Press.

Qusti, Raid. (2006). “Court Case Against Rajaa Al-Sanea”. www.arabnews.com Mon. 2006-10-09.

Rajkhan, S. (2014). Women in Saudi Arabia: Status, Rights, and Limitations.Bothell: University of Washington Bothell.

Syahril. (2014). "Arena of Cultural Production and Symbolic Violence against Banaat ar-Riyadh Novel: Sociological Perspective Pierre Bourdieu" in Journal Peuradeun Vol 2, Number 1, January 2014. SCAD Independent. p 75-82.

Sumayyah, Alalami. (2019). "Identity Crises in Contemporary Saudi Arabian Women's Writing". PhD Thesis. Arabic and Middle Eastern Studies, Faculty of Arts, Humanities, and Culture. University of Leeds.

Thalib, Amirah Anis. (2013). “Saudi Arabian Women's Marriage Life in Girls of Riyadh, a Novel by Rajaa Alsanea: Subordination and Struggle". Faculty of Culture Studies, Universitas Brawijaya. https:// media.neliti.com/media/publications/187143

Tomlinson, J. (1999). Globalization and culture. Chicago: University of Chicago Press.

Tribunnews. (2018). 11 Larangan yang Harus Dipatuhi Wanita Arab Saudi, Termasuk Tidak Boleh Naik Transportasi Umum. From www.tribunnews.com. Accessed on June 20, 2018.

Ware, Vron. (2010). "The New Literary Front: Public Diplomacy and the Cultural Politics of Reading Arabic Fiction in Translation"

Waters, M. (1995). Globalization. London and New York: Routledge. 